The Tribute of Blood 
$A$ book in the series

Latin America Otherwise

Languages, Empires, Nations

Series editors:

Walter D. Mignolo, Duke University

Irene Silverblatt, Duke University

Sonia Saldivar-Hull, University of California

at Los Angeles 


\section{The Tribute of Blood}

ARMY, HONOR, RACE, AND NATION

IN BRAZIL, I864-I945 Peter M. Beattie

DUKE UNIVERSITY PRESS

Durham \& London

$200 I$ 
2nd printing, 2007

(C) 200 I Duke University Press All rights reserved

Printed in the United States of America on acid-free paper $\infty$

Designed by C. H. Westmoreland Typeset in Carter \& Cohn

Galliard with Franklin Gothic display by Keystone Typesetting, Inc.

Library of Congress Cataloging-in-Publication Data appear

on the last printed page of this book. 